\title{
The Role of Subsidized Fertilizers on Rice Production and Income of Farmers in Various Land Typologies
}

\author{
Elisa Wildayana*, and M Edi Armanto \\ Faculty of Agriculture, Sriwijaya University, South Sumatra Indonesia \\ Corresponding Author: ewildayana@unsri.ac.id
}

Recieved: October 2018 | Revised: January 2019 | Accepted: March 2019

\begin{abstract}
The research aimed to analyze the role of subsidized fertilizers on rice production and income of farmers in various land typologies. The sampling used is cluster method and followed with an experimental research by using Split Plot Design. The compound fertilizer costs are one-half times higher than single fertilizer, but the rice yield difference is enhanced by the provision of fertilizer reaching more than two-times higher compared to a single fertilizer. The rice yields can be increased more than three-times higher, but the income of farmers can be increased only about one and half times. The Government needs to make a policy of the lowest rice price, then income of farmers can be automatically increased and at the same time the welfare of famer's families will be also increased.
\end{abstract}

Keywords: Role, subsidized fertilizers, rice, production, income, land typologies JEL Classification: Q24, Q18, H23

How to Cite: Wildayana, E., \& Armanto, M. (2019). The Role of Subsidized Fertilizers on Rice Production and Income of Farmers in Various Land Typologies. Jurnal Ekonomi Pembangunan: Kajian Masalah Ekonomi dan Pembangunan, 20(1). doi:https://doi.org/10.23917/jep.v20i1.7081

DOI: https://doi.org/10.23917/jep.v20i1.7081

\section{Introduction}

Food crop farming (especially rice) belongs to a very important sector in the development of regional economy because rice is utilized as the staple food in tropical countries and can be processed for various food products. Rice also contain carbohydrates, minerals and contain a variety of vitamins that are needed by human life. In addition, the remnants of the rice harvest can be used as livestock feed and pedestal enclosures, industrial raw materials and others (Kazukauskas, Newman \& Sauer, 2014; Larson, Otsuka, Matsumoto, \& Kilic, 2014).

Increasing the rice production is presently constrained by the limited availability of fertile soils for the extension of rice farming because most of fertile soils are converted for nonagricultural purposes due to being pressured by the rapid population growth. Thus the use of marginal soils are utilized for developing rice production in order to fulfill the need for increased public demand for rice. The marginal soils used for rice farming needs continuously necessary to fertilization (Ricker-Gilbert, 2014; Takeshima \& Nkonya, 2014).

The Government has been anticipating increasing demand for fertilizers through fertilizer subsidy policy. Since 1971 subsidized fertilizer policy has played crucial role in rice production. The purpose of the fertilizer subsidy is to increase food security, to reduce the farming cost by farmers, to improve the welfare of farmers and at the same time to increase the rice production. With fertilizer subsidy, farmers are not difficult to obtain fertilizer at the farmer level with the HET price (the highest retail price) and the fertilizer subsidy can remain affordable for farmers, especially small farmers, so as to support 
Jurnal Ekonomi Pembangunan: Kajian Masalah Ekonomi dan Pembangunan, 20 (1), 2019, 100-107

increased productivity of farmers and farming, as well as support the food security program (Ramli, Shamsudin, Mohamed, \& Radam, 2012).

Beside that fertilizer subsidy policy is driven by the condition that the rice farming is able to absorb over $24 \%$ of the total workforce in Indonesia and is able to contribute more than $11.34 \%$ to the total Gross National Product (GNP). Therefore the role of the agricultural sector should be supported by the fertilizer subsidy policy (Adriani, Wildayana, Yulius, \& Haki., 2017; Adriani, Zahri, Wildayana, \& Hamzah, 2018). The HET prices are only valid fertilizers of SP36, Urea and ZA in packs of $50 \mathrm{~kg}$ and $20 \mathrm{~kg}$ for NPK and paid in cash by the farmers to the authorized retailer in the countryside (Zahri, Adriani, Wildayana, Kadir, \& Umar, 2018; Wildayana, Armanto, Zahri, \& Hasan, 2017).

Provision of fertilizer subsidies in the long term can increase the amount of fertilizer consumption. This increase is able improve positive and negative effects; on the one hand the positive effect is to increase rice production, but on the other hand it can improve the subsidy issued by the Government each year. Excessive use of fertilizers also have a negative impact on the environment. Thus the government is trying to reduce the amount of fertilizer subsidy budget from year to year. Then at the beginning 1997 (where the financial crisis has occurred) the fertilizer subsidy was abolished in December 1998. In 2001 after the financial crisis the fertilizer subsidy is restricted only for food crops, especially rice, while plantation crops follow the market price and the Government will continue to gradually reduce subsidies on fertilizer in order to rice farming becoming efficient, efficient and sustainably (Wildayana \& Armanto, 2018; Adriani $\&$ Wildayana, 2015). The fertilizer subsidy is only purposed for food crops, because it is based on the fact that the role of fertilizer is very important in improving the productivity and yield of food crops in agricultural commodities, making fertilizer as a strategic means of production (Wildayana, 2017).
Based on their contents, the subsidized fertilizers are divided into two kinds, namely single fertilizers (e.g. Urea, SP36, ZA) and compound fertilizers (like $\mathrm{NPK}_{\text {Phonska }}$ with composition of $\mathrm{N}: \mathrm{P}: \mathrm{K}$ of $15: 15: 15$ and $20: 10$. The principle of provision of subsidized fertilizers has to meet six criteria, namely the accuracy of time, type, quantity, price, location and quality (Adzemi et al., 2017; Rachman and Sudaryanto, 2010). The use of lime, Urea, SP36, $\mathrm{KCl}$, and micro fertilizer is one of the important requirements to obtain adequate rice production and rice plants absorb nitrogen, phosphorus and potassium in relatively large quantities. Nitrogen fertilization with dose and the right time can significantly affect the increase in uptake of N, P, K, plant dry weight and seed yield of rice (Armanto, Susanto, \& Wildayana, 2017; Armanto, Imanudin, Wildayana, Junedi, \& Zuhdi, 2016).

Provision of fertilizer to the rice plants in a rational and useful amounts can increase rice yields. The effect of adding fertilizer to the soil is to create a high level of nutrients, and can increase the production and quality of rice plants. In connection with the above issues of subsidized fertilizer and to achieve fulfilling the six principles of accuracy, thus it is necessary to study the role of subsidized fertilizers on rice production and income of farmers in various land typologies. It is expected that this research can be utilized as an input for the Government to improve the application of subsidized fertilizer at the farmer level effectively, efficiently and sustainably.

\section{Research Method}

The research location was determined by intentionally purposive method in consideration of each location chosen to represent each land typology to be studied and the chosen location is the regions that are cultivated with rice farming for each typology. The sampling method used is cluster sampling (sampling area). From the South Sumatra province, it was taken four districts considered to represent a land typology to be studied and as an area of rice production 
Jurnal Ekonomi Pembangunan: Kajian Masalah Ekonomi dan Pembangunan, 20 (1), 2019, 100-107

centers. From each district were taken again two to four sub-districts which have a village with the land typology studied.

Of each land typology respondents were interviewed with method of disproportionate stratified random sampling. After determining the research location, an experimental research by using Split Plot Design with two factors was conducted, namely the first factor (F) determining Main Plots is fertilizer type covering a single fertilizer $\left(\mathrm{F}_{0}\right)$ and compound fertilizer $\left(\mathrm{F}_{1}\right)$ and the second factor (R) named as Sub Plots is land typology, namely tidal ricefields $\left(\mathrm{R}_{0}\right)$; rainfed ricefields $\left(\mathrm{R}_{1}\right)$; lebak ricefields $\left(\mathrm{R}_{2}\right)$; and technically irrigated ricefields $\left(\mathrm{R}_{3}\right)$.

The difference in soil productivity level is largely determined by the ability to regulate the water availability for rice plants. The water conditions in tidal ricefields are difficult to be managed because they depend very strong on the tide conditions. Water management in the rainfed ricefields is easier to be managed through making water reservoir (pond and water storage). The availability of fresh water in lebak ricefields is much better and available for most of the year, while technically irrigated ricefields show the most perfect water management compared to other rice fields.

Combination treatment was $2 \times 4=8$, and any combination treatment was repeated ten times (stating the number of research plots in the field). Overall the number of combined treatment is $2 \times 4 \times 10=80$ combinations of treatments. The observed data are rice yields, fertilizer costs and income of farmers. Data obtained were statistically processed by analysis of variance (two-ways ANOVA). If the results of variance showed significant differences, then it was continued with Posthoc LSD Test (Least Significance Difference) with a confidence level of $5 \%$, whereas if the result of variance showed a significant difference, then it was continued with Posthoc LSD Test with a confidence level of $1 \%$.

\section{Results and Discussion}

The results and discussion of the research will be focused on the following items, namely characteristics of ricefields in South Sumatra; the role of subsidized fertilizers on rice growth, fertilizer costs paid by farmers and income of farmers in various land typologies.

\subsection{Characteristics of Ricefields in South Sumatra}

South Sumatra belong to the agricultural region having the various potential of rice farming, ranging from technical irrigated ricefields, rainfed, lebak and tidal. Generally ricefields are farming land that the soil surface is always flat and if the fields are in the hilly contours, then formed terracing, mostly planted with rice, so it requires intensive irrigation. Soil cultivation is mostly done on the condition of saturated water. During the dry season the ricefields are often used for cereals or short-lived crops (such as corn, green beans, peanuts, and others).

The soil fertility is more stable than dry land, thus it is allowing intensively cultivated without any drastic decline in productivity. In general, ricefield productivity is higher (4.10-4.56 tons MDG (Milled dry grains)/ha/year) than dry land or shifting cultivation (1.00-2.00 tons MDG/ ha/year). Ricefields generally have relatively regular water sources except rainfed. The main crop is rice cultivated and soil nutrients derived from the input material from outside. Under the conditions of a stable character ricefields good views of the physical aspects of ricefields, and fertility ricefields, then it is very likely studied how the role of the subsidized fertilizer at various ricefields.

\subsubsection{Technically Irrigated Ricefields}

Technically irrigated ricefields is an agricultural system with technical irrigation systems that are measurable and regularly 
Jurnal Ekonomi Pembangunan: Kajian Masalah Ekonomi dan Pembangunan, 20 (1), 2019, 100-107

technical watered, do not rely on rainfall for irrigation systems. The irrigation water can be obtained from the dam, reservoir or river either artificial or natural. Irrigation system is carried out by the groups of farmers. Water entering the plots of ricefields have been measured, because the settings are good enough to use the equipment, so that water entering into the channels of tertiary and secondary are already counted the amount or debits. Harvesting is done two or three times a year and in the dry season can be interspersed with cereals crops, such as corn, green beans, peanuts, and others. Technically irrigated ricefields in South Sumatra are approximately an area of 36 thousands ha and is the narrowest area of ricefields in South Sumatra Province with rice productivity of 4.28-13.55 tons MDG/ha/year.

\subsubsection{Rainfed Ricefields}

Rainfed ricefields are getting water only during the rainy season, so it is very dependent on the rainy season. Rainfed ricefields are directly planted with Gogo rice cultivation types. However, in the dry season is planted with cereal crops, mainly maize and cassava or left fallow. Rainfed ricefield productivity is generally low due to degraded soil conditions, high evaporation, drought, flooding, and lack of water management. Farmers also potentially carry out replanting of rice plants more often than irrigated ricefields, due to unstable water supply. In South Sumatra there are approximately 75 thousands ha of rainfed ricefields with rice productivity of 4.568.70 tons MDG/ha/year.

\subsubsection{Lebak Ricefields}

Lebak ricefields are generally found along the large and wide rivers, for example the Musi River, and a source of irrigation water comes from the large rivers or rainwater. This lebak ricefields are located in lowland or depression area which there is usually no entry point for water or drainage. Soil tillage is not required, even preferred not to do tillage because it can trigger to oxidize a Fe2S (pyrite) compound causing acidic condition. In lebak ricefields eels are very often found because live of eels requires wet conditions all the time. There is a typical weeds in lebak ricefields which is relatively difficult to control, namely Ganepo, a kind of weeds that exist on the surface of the water and its leaves resemble the leaves of taro watertight because the surface of the leaves have a sort of fuzz.

Lebak ricefields are usually planted ahead of the dry season and the harvest before the rainy season or during the dry season, so the harvest before the rainy season or even at the beginning of the rainy season due to avoid potential flooding during the rainy season. Rice plant on the lebak ricefields usually lives longer than the rice in other ricefields because almost every time lebak ricefields are inundated. Therefore it needs to make some kind of drainage channels to the interests and dispose of excess iron content, which marked the water color is commonly called pyrite oxidation. In South Sumatra there are approximately 131 thousands ha of lebak ricefields and is the second largest after the tidal ricefields with rice productivity of 4.21-8.83 tons MDG/ha/year.

\subsubsection{Tidal Ricefields}

Tidal ricefields is a rice farm with irrigation system depends on the state of the surface water is affected by the condition of the ebb and flow of sea water and river water. At the time of high tide, the tidal ricefields inundated by water, whereas at low tide, the tidal ricefields be dried and planted with rice. Tidal ricefields are commonly located in the area close to the sea, so that the irrigation system has greatly influenced the tide of water in and out to the ricefields plots which are set using a valve system made specifically between ricefields plots. Extensive tidal ricefields in South Sumatra ranges around 170 thousands ha and belongs to the largest swamp area in South Sumatra with rice productivity of 4.10-4.43 tons MDG/ha/year. 
Jurnal Ekonomi Pembangunan: Kajian Masalah Ekonomi dan Pembangunan, 20 (1), 2019, 100-107

\subsection{The Role of Subsidized Fertilizers on Rice Growth in Various Land Typologies}

Table 1. The role of subsidized fertilizers on rice growth in various land typologies

\begin{tabular}{ccccccc}
\hline \multirow{2}{*}{ Treatment } & \multicolumn{5}{c}{ Plant height of rice at week $(\mathbf{c m})^{* * * /}$} \\
\cline { 2 - 6 } & $\mathbf{1}^{\text {st }}$ & $\mathbf{2}^{\text {nd }}$ & $\mathbf{4}^{\text {th }}$ & $\mathbf{5}^{\text {th }}$ & $\mathbf{7}^{\text {th }}$ & $\mathbf{8}^{\text {th }}$ \\
\hline $\mathrm{F}_{0} \mathrm{R}_{0}$ & 6.83 & 19.49 & 30.79 & 38.81 & $42.16^{\mathrm{a}}$ & $45.01^{\mathrm{a}}$ \\
$\mathrm{F}_{0} \mathrm{R}_{1}$ & 12.76 & 21.48 & 33.79 & 40.48 & $45.68^{\mathrm{ab}}$ & $50.18^{\mathrm{b}}$ \\
$\mathrm{F}_{0} \mathrm{R}_{2}$ & 13.02 & 21.49 & 33.20 & 41.40 & $44.49^{\mathrm{a}}$ & $47.34^{\mathrm{a}}$ \\
$\mathrm{F}_{0} \mathrm{R}_{3}$ & 11.63 & 19.40 & 33.21 & 40.30 & $42.79^{\mathrm{a}}$ & $45.10^{\mathrm{a}}$ \\
$\mathrm{F}_{1} \mathrm{R}_{0}$ & 12.54 & 22.38 & 34.31 & 42.26 & $46.54^{\mathrm{bc}}$ & $50.34^{\mathrm{b}}$ \\
$\mathrm{F}_{1} \mathrm{R}_{1}$ & 12.58 & 22.36 & 35.11 & 43.35 & $49.66^{\mathrm{c}}$ & $56.68^{\mathrm{c}}$ \\
$\mathrm{F}_{1} \mathrm{R}_{2}$ & 12.79 & 21.70 & 37.49 & 44.49 & $46.66^{\mathrm{bc}}$ & $50.01^{\mathrm{b}}$ \\
$\mathrm{F}_{1} \mathrm{R}_{3}$ & 12.20 & 23.40 & 36.78 & 43.21 & $50.68^{\mathrm{c}}$ & $55.66^{\mathrm{c}}$ \\
\hline $\mathrm{BNT}^{*} l_{(0.05)}$ & $\mathrm{ns}$ & $\mathrm{ns}$ & $\mathrm{ns}$ & $\mathrm{ns}$ & 1.96 & 2.62 \\
\hline
\end{tabular}

Note: */ Test of LSD (Least Significance Different); ns: not significant

$* * /$ the average values of the treatment in the same column are indicated with the same superscript letter meaning not different significantly at 5\%-level

Subsidized fertilizer treatment effect on the growth of rice plants at different land typology. One of measured parameter for rice growth is indicated by rice plant height because it reflects the appearance of vegetative growth of the rice plants. If in the eighth week the rice plant height has reached more than 50 $\mathrm{cm}$, it means that the vegetative growth of rice has reached optimal condition for achieving optimal generative growth. However, if the rice plant height exceeds $70 \mathrm{~cm}$, the impact is that the vegetative growth would be pressing the generative growth, and usually rice plant will fall down due to blowing wind and rice yields will also fall rapidly. Rice plant height data were obtained from interviews with respondents, it turns out until the sixth week after planting, giving subsidized fertilizer did not effect on rice plant height in all the land typology. This is due to fertilizers applied do not interact yet optimally with soils, thus rice plants are not able to absorb soil nutrients optimally.

But on the seventh and eighth weeks after planting, most soil nutrients from fertilizers are completely dissolved in the soils water and to form soil nutrients available to rice plants. Subsidized fertilizer significantly affected the rice plant height. Plant height data only were recorded only until the end of vegetative growth of rice plants. Subsidized fertilizer interaction with land typology can increase rice plant height compared with controls, i.e. the treatment of single fertilizer on tidal ricefields which had the lowest average height of rice plant (Table 1). Optimal interaction was fully demonstrated by the provision of compound fertilizer on rainfed ricefields and technically irrigated ricefields and significantly different with other treatments, while single fertilizer treatment on all land typology showed the lowest height of rice plant. 
Jurnal Ekonomi Pembangunan: Kajian Masalah Ekonomi dan Pembangunan, 20 (1), 2019, 100-107

\subsection{The Role of Subsidized Fertilizers on Fertilizer Costs paid by Farmers in Various Land Typologies}

Table 2. The role of subsidized fertilizers on fertilizer cost, rice yields and income of farmers

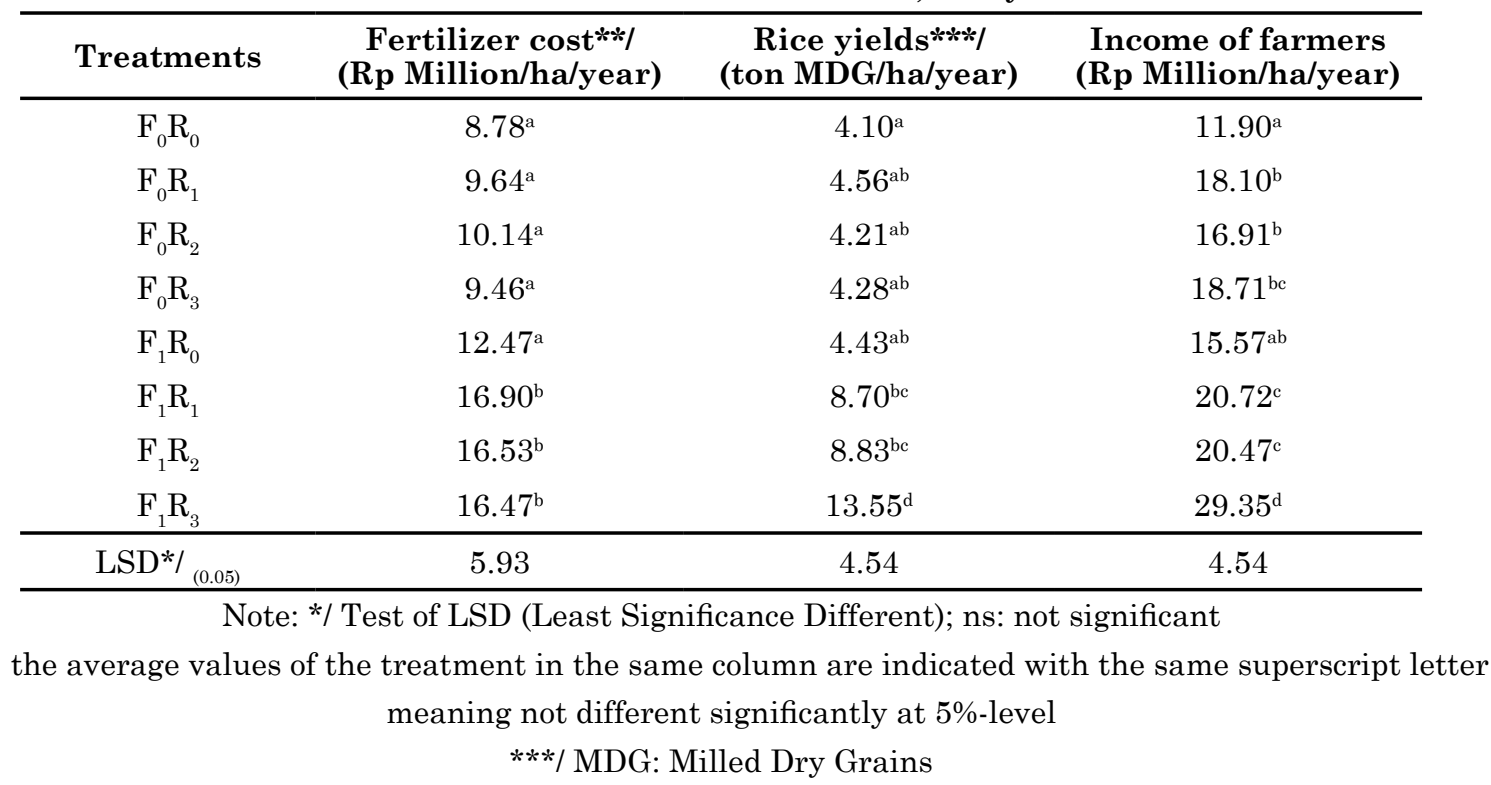

Based on advanced test of LSD 5\% showed subsidized fertilizer at various land typology affect significantly the fertilizer cost (Table 2). Fertilizer costs shows there is significant interaction between the fertilizer types at various land typology. Single fertilizer application indicates a lower cost and significantly different compared to the compound fertilizer. This indicates that a compound fertilizer could increase the fertilizer cost, especially on the typology of rainfed, lebak and tidal ricefields as well as in technical irrigation ricefields. Combination treatment wherein compound fertilizer given to rainfed ricefield and lebak ricefields showed that fertilizer costs are the highest, i.e. respectively $\mathrm{Rp} 16.90$ and $16.53 \mathrm{Million} / \mathrm{ha} /$ year. It is understandable why farmers prefer to use a single fertilizer rather than compound fertilizers. As comparison that the cost of compound fertilizer is around $150 \%$ higher than single fertilizer cost.

\subsection{The Role of Subsidized Fertilizers on} Rice Yields in Various Land Typologies

Based on advanced test of LSD 5\% showed subsidized fertilizer at various land typology affect significantly the rice yields (Table 2). Rice yields showed a significantly different effect between single fertilizer and compound fertilizer. Land typology fertilized with compound fertilizer showed higher rice yields and significantly different with land typology fertilized with a single fertilizers. This proves that the higher the dose of compound fertilizer in various land typology is, the higher the nutrients are available. Compound fertilizer in various land typology showed highly significantly different compared with the controls (single fertilizer) because single fertilizers are able to supply only certain soil nutrients.

Although compound fertilizer costs increase one-half times (150\%) higher than single fertilizer, but the rice yield difference is enhanced by the provision of fertilizer reaching more than $200 \%$ (two-times higher) compared to a single fertilizer. This means that compound fertilizers remain more profitable for all land typology and the highest profit achieved by technically irrigated ricefields (rice yield is three times higher or $300 \%)$. 
3.5 The Role of Subsidized Fertilizers on Income of Farmers in Various Land Typologies

Based on advanced test of LSD 5\% showed subsidized fertilizer at various land typology affect significantly the income of farmers (Table 2). Subsidized fertilizer at various land typology affect significantly the increase in income of farmers. In rainfed ricefields fertilized with compound fertilizers gave the most efficient treatment in increasing the income of farmers. Income of farmers showed a slightly different phenomena with rice yields. Compound fertilizers at various land typology are proven to increase the income of farmers and significantly different with various land typology fertilized with single fertilizers. Although rice yields can be increased more than three-times higher (200\%) especially in technical irrigated ricefieds, but the income of farmers cannot be increased three-times higher. The increase in income of farmers is around about one and half times ( $150 \%$ higher). This is due to the income of farmers is determined by the market price of rice, fluctuating prices in the market does not endorse the fact that the more rice production is achieved, the more income of farmers is earned by farmers. At the time of this study, then setting of the rice price was determined by traders and retailers, while the Government is unable to control the rice price in the market. Therefore, when the Government issued a supposedly production development policy of the lowest rice price, then income of farmers can be automatically increased and at the same time the welfare of famer's families also increased.

\section{Conclusions}

From the results and discussion of this research, it can be summarized some conclusions as follows: The compound fertilizer costs increase one-half times (150\%) higher than single fertilizer, but the rice yield difference is enhanced by the provision of fertilizer reaching more than $200 \%$ (two-times higher) compared to a single fertilizer. The rice yields can be increased more than three- times higher $(300 \%)$, but the income of farmers cannot be increased only about one and half times (150\% higher). The Government needs to issue a policy of the lowest rice price, then income of farmers can be automatically increased and at the same time the welfare of famer's families also increased.

\section{Acknowledgement}

This paper is a part of our main research funded by "Penelitian Unggulan Profesi Dosen", Sriwijaya University. Reference Project Nr. 0006/UN9/SK.LP2M.PT/2018 dated on 05 June 2018. The authors are indebted and express appreciation and gratitude to all those who have helped and facilitated this research in the fields, particularly to Staffs of Faculty of Agriculture Unsri, graduate and post-graduate students as well as local residents.

\section{References}

Adriani D., Wildayana, E., Yulius, I. A., \& Hakim, M.M. (2017), Technological Innovation and Business Diversification: Sustainability Livelihoods Improvement Scenario of Rice Farmer Household in Sub-Optimal Land. Russian Journal of Agricultural and SocioEconomic Sciences, Vol 9 (69); 77-88

Adriani, D., \& Wildayana, E. (2015). Integrasi Pertumbuhan Ekonomi dan Penciptaan Kesempatan Kerja Sektor Pertanian di Indonesia. Sosiohumaniora, 17(3), 269-275.

Adriani, D., Zahri, I., Wildayana, E., \& Hamzah, M. (2018, February). Farmer's welfare in Telang's integrated independent city: lesson learned from migrant and local farmers in tidal land, South Sumatera. In IOP Conference Series: Earth and Environmental Science (Vol. 122, No. 1, p. 012013). IOP Publishing.

Adzemi, M.A., Armanto, M.E. \& Wildayana, E. (2017), BRIS Soil Improvement for Sustainable Crop Production. LAP LAMBERT Academic Publishing. Web-link: https://www.lap-publishing.com pages: 76 . 
Armanto, M. E., Imanudin, M. S., Wildayana, E., Junedi, H., \& Zuhdi, M. (2016). Managing actual problems of peatsoils associated with soil acidity. Sriwijaya Journal of Environment, 1(3), 58-63.

Armanto, M. E., Susanto, R. H., \& Wildayana, E. (2017). Functions of Lebak swamp before and after landfills in Jakabaring South Sumatra. Sriwijaya Journal of Environment, 2(1), 1-7.

Kazukauskas, A., Newman, C., \& Sauer, J. (2014). The impact of decoupled subsidies on productivity in agriculture: a cross $\square$ country analysis using microdata. Agricultural economics, 45(3), 327-336.

Larson, D. F., Otsuka, K., Matsumoto, T., \& Kilic, T. (2012). Should African rural development strategies depend on smallholder farms? An exploration of the inverse productivity hypothesis. Agricultural Economics, 45(3); 355-367

Rachman, B. \& Sudaryanto, T. (2010), Impacts and Future Perspectives of Fertilizer Policy in Indonesia. Analisis Kebijakan Pertanian. Vol 8(3); 193-205

Ramli, N. N., Shamsudin, M. N., Mohamed, Z., \& Radam, A. (2012). The impact of fertilizer subsidy on Malaysia paddy/ rice industry using a system dynamics approach. International Journal of Social Science and Humanity, 2(3), 213-219.
Ricker $\square$ Gilbert, J. (2014). Wage and employment effects of Malawi's fertilizer subsidy program. Agricultural Economics, 45(3), 337-353.

Takeshima, H., \& Nkonya, E. (2014). Government fertilizer subsidy and commercial sector fertilizer demand: Evidence from the Federal Market Stabilization Program (FMSP) in Nigeria. Food Policy, 47, 1-12.

Wildayana, E. (2017). Challenging constraints of livelihoods for farmers on the South Sumatra Peatlands, Indonesia. Bulgarian Journal of Agricultural Science, 23(6), 894905.

Wildayana, E., \& Armanto, M. E. (2018). Dynamics of landuse changes and general perception of farmers on South Sumatra Wetlands. Bulg. J. Agric. Sci, 24(2), 180188.

Wildayana, E., Armanto, M. E., Zahri, I., \& Hasan, M. Y. (2017). Novel innovation of subsidized fertilizers based on soil variability and farmer's perception. Jurnal Ekonomi Pembangunan: Kajian Masalah Ekonomi dan Pembangunan, 18(1), 50-63.

Zahri, I., Adriani, D., Wildayana, E., Kadir, S., \& Umar, H. (2018). Comparing Rice Farming Apperance of Different Agroecosystem in South Sumatra, Indonesia. Bulgarian Journal of Agricultural Science, 24(2), 189198. 